
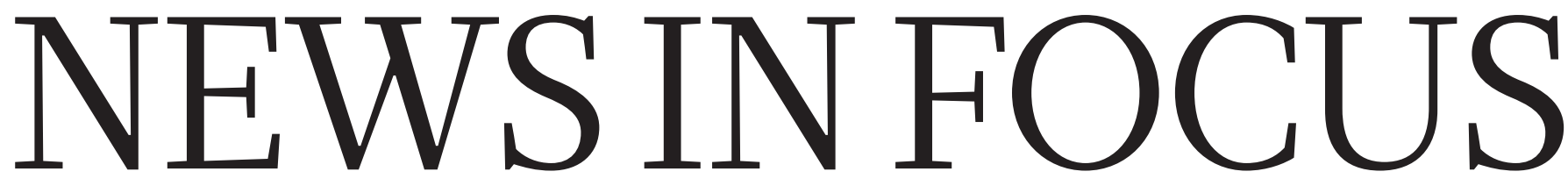

SPACE Plate tectonics on

Jupiter moon buoys bid for trip to Europa $\mathbf{p} .153$
CHINA Scientist weighs in on earthquake-reservoir link p.154
TECHNOLOGY Astronauts to take delivery of their own 3D printer $\mathbf{p} .156$

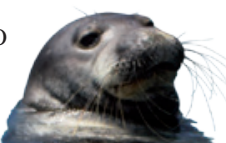

PHYSIOLOGY Fitness

trackers fuel wildlife biology craze $\mathbf{p} .157$

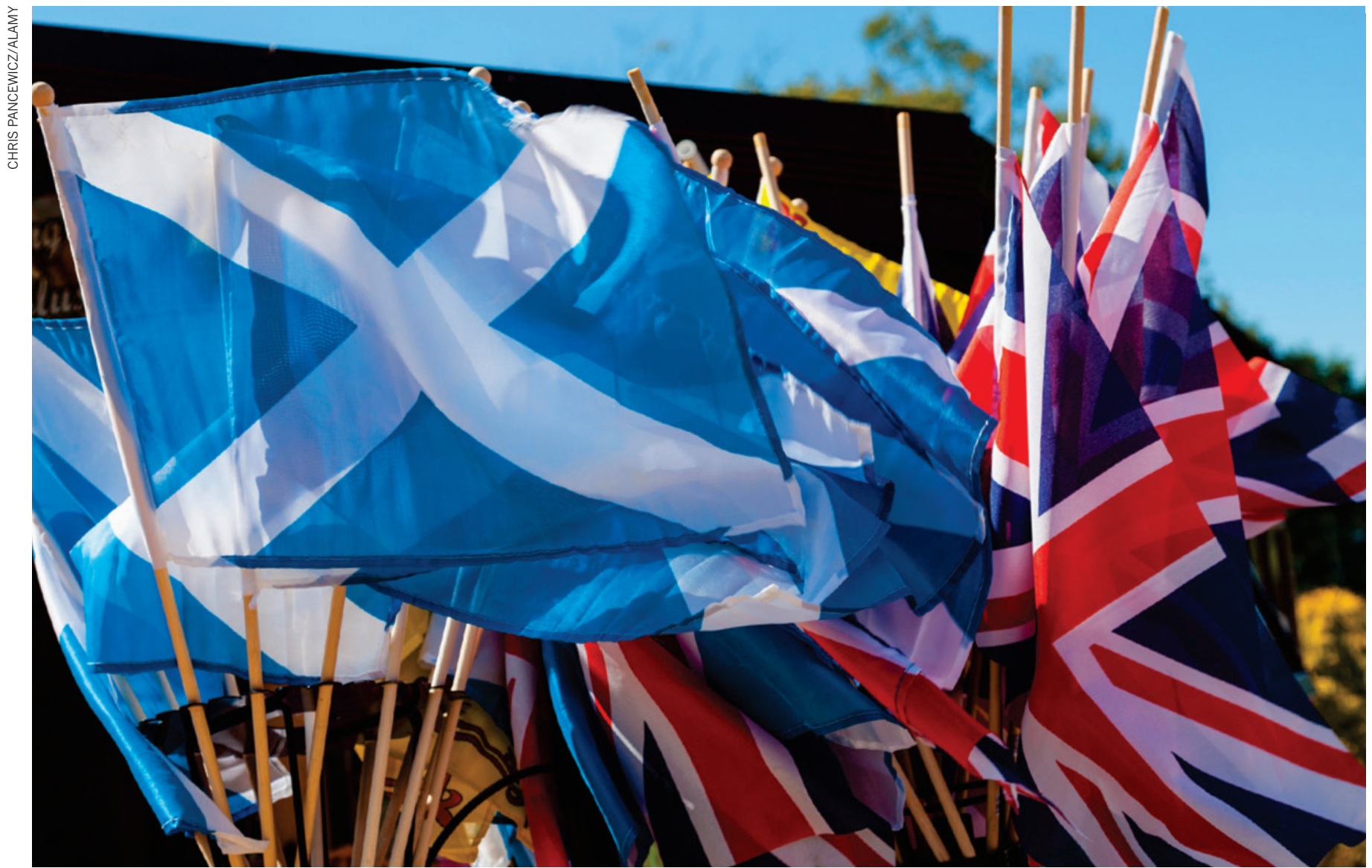

People in Scotland will be voting on whether they want their country to remain as part of the United Kingdom.

\title{
POLITICS
}

\section{Scientists split over Scottish independence vote}

\section{Research could founder or flourish if Scotland leaves the United Kingdom.}

\section{BY ELIZABETH GIBNEY}

$\mathrm{D}$ olly the cloned sheep was created there; the existence of the Higgs boson was predicted there. But soon Scotland could leave the United Kingdom, with potentially major repercussions for science. Ahead of a historic referendum on 18 September, which the latest opinion polls suggest could go either way, researchers on both sides of the border are split over whether science in Scotland would flourish or founder should its people vote yes to independence.

Although many scientists are reluctant to speak out in a political debate that is fast becoming acrimonious, a few are weighing in. Meanwhile, rival university-based groups, 'Academics for Yes' and 'Academics Together', which draw support from across the humanities and sciences, are busy arguing their cases.

Those in the 'no' camp fear a nation turning in on itself, and the end of a status quo that sees Scotland's scientists produce more papers per head, and receive more citations per paper, 
- than the UK average (see 'Scottish success').

Other academics argue that a 'yes' vote would give Scotland the freedom to devote more money to science and to organize research to better fit the country's needs. They note that Scotland's science benefited from changes pioneered since the formation of the Scottish government in 1999 , a form of independence that devolved certain powers to Scotland, including health and education spending.

One thing is clear: the patchwork of sources from which Scottish institutes currently obtain their funding means that a vote for independence would create complexity. These sources include the European Union, with which Scotland would have to renegotiate membership; bodies specific to Scotland, which may be least affected by independence; and sources that pool money from across the United Kingdom.

The focus of most disagreement is the panUK government body Research Councils UK (RCUK), which is responsible for sharing out some $£ 2.9$ billion (US $\$ 4.7$ billion) of tax income collected from England, Scotland, Wales and Northern Ireland. In 2012-13, Scottish institutions received an outsized share of this pot: $10.7 \%$ of the total RCUK spending - $13.1 \%$ if only university research is taken into account even though Scotland's population is just $8.4 \%$ of the UK total and its tax contribution only $9 \%$. Although small, this difference between what Scotland puts in and takes out might mean a net loss for an independent Scotland, says Omid Omidvar, a social scientist at the University of Coventry in England, who has studied the future of science if independence goes ahead.

The Scottish government, which is spearheading the push for independence, says that it will negotiate a formula for still paying into, and receiving money from, a common research funding system, and will make up any shortfall. Others say that this is wishful thinking. Earlier this year, the RCUK stated that, "Should there be a vote for independence, the current system could not continue". Keeping Scotland in the RCUK would not be practical, says Hugh Pennington, an emeritus bacteriologist at the University of Aberdeen in Scotland, and a leader of Academics Together, which opposes independence. The desire to ensure that each country gets out what it pays in would cloud decisions and make it difficult to allocate funding in a location-neutral manner, he says. "Scotland is walking away. I think the RCUK would say, 'Fund your own research, Sunshine."

Other funding sources would also face changes if Scotland were to leave. Members of the Association of Medical Research Charities invested around $£ 1.1$ billion in research in 2011, with $13 \%$ of it spent in Scotland. One of the association's wealthiest members, the Londonbased Wellcome Trust, says that it is unlikely to stop funding Scottish projects entirely if the nation votes 'yes', but that it would review the eligibility of institutions there.

Another issue is ease of access to world-class infrastructure, such as the RCUK-funded Diamond Light Source synchotron near Didcot in England. The resource is used by a range of disciplines for studying matter at the molecular and atomic level. Omidvar says that big questions remain over who would own such sites, which are currently shared between the countries that make up the United Kingdom.

English geneticist and Nobel prizewinner Paul Nurse, who is president of the Royal Society in London, told an audience at the University of Edinburgh in July of his fears that establishing a UK-Scotland border would hinder the "open, liquid and dynamic exchanges" under which science thrives.

Scotland's influence over decision-making in science could be affected, too. Pennington believes that if an independent Scotland joined

\section{SCOTTISH SUCCESS}

Scottish researchers are more productive than researchers in the United Kingdom as a whole and in many other countries.

2.0

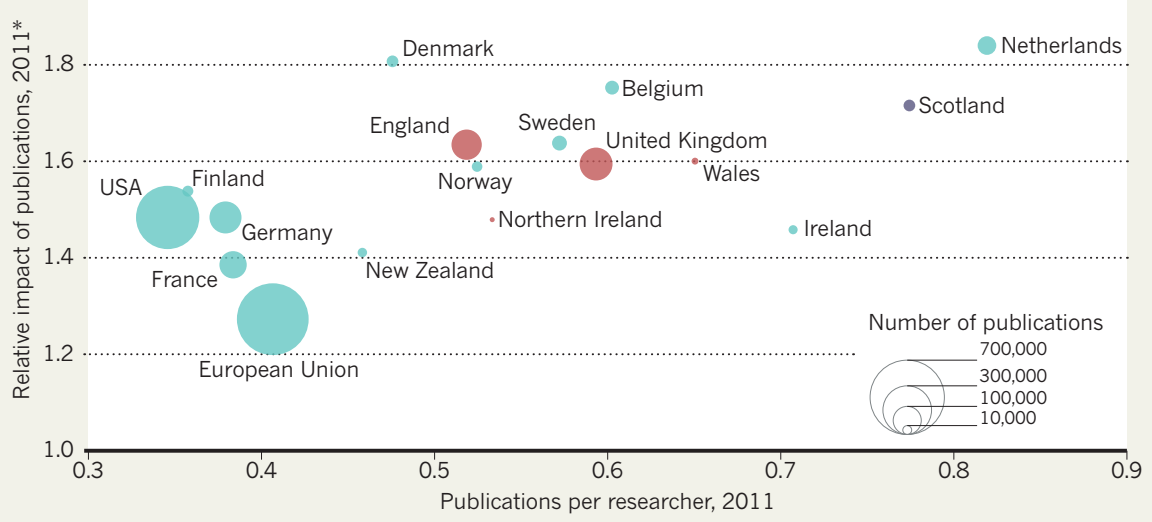

*Mean citations per article, normalizing for subject field and year of publication; relative to world average $=1$. the European Space Agency, say, the country would become "a relatively small player in a big club, where a few big members have the loudest voices". And some scientists fear that research might become more parochial. One senior Scottish scientist who opposes independence, and who did not want to be named, said that he preferred decisions on research funding to come from London or Swindon, where the RCUK is based, rather than from a small scientific community that would be subject to the sway "of a few very dominant personalities".

Those in the 'yes' camp dismiss such fears, and emphasize the opportunities presented by independence. Bryan MacGregor, a land economist, vice-principal at the University of Aberdeen and a member of Academics for Yes, says that he sees this as a chance to devote a greater portion of government money to research. "In the United Kingdom, we're already spending less on research and development than

\section{The trend for innovation would continue under full independence.} virtually all our competitors," he says. He notes that further cuts in public spending are planned. "I don't see how the science budget won't be hit."

Independence would also give Scotland more leverage over science policy and spending, according to the Scottish government. Decisions on taxation and how to allocate tax credits, in which companies receive financial incentives for investing in science, are currently controlled centrally. MacGregor sees a chance to boost the amount that businesses spend on science in Scotland.

The creation of the Scottish government has already had positive effects on Scottish science. The government has pioneered some original approaches, including the creation of innovation centres, which support collaborations between universities and businesses, and 'research pools' - discipline-specific networks that span different institutions. The trend would continue under full independence, says Murray Pittock, a professor of English who is a vice-principal of the University of Glasgow in Scotland and a member of Academics for Yes.

An independent Scotland would reverse UK immigration policies that the Scottish government says are damaging universities. These include reinstating post-study work visas, which allowed foreign students to work in the United Kingdom for two years once they had finished their degrees and which was scrapped in 2012.

MacGregor says that many of the statements coming from the 'no' campaign are based on fear, and overlook the potential opportunities. But for Pennington, risking a successful research system for the promise of independence is simply not worth it: "If the [Scottish] government had put in its white paper that they were going to raise the university budget threefold, I might have reconsidered my position. At best, what they offer is no change." 